
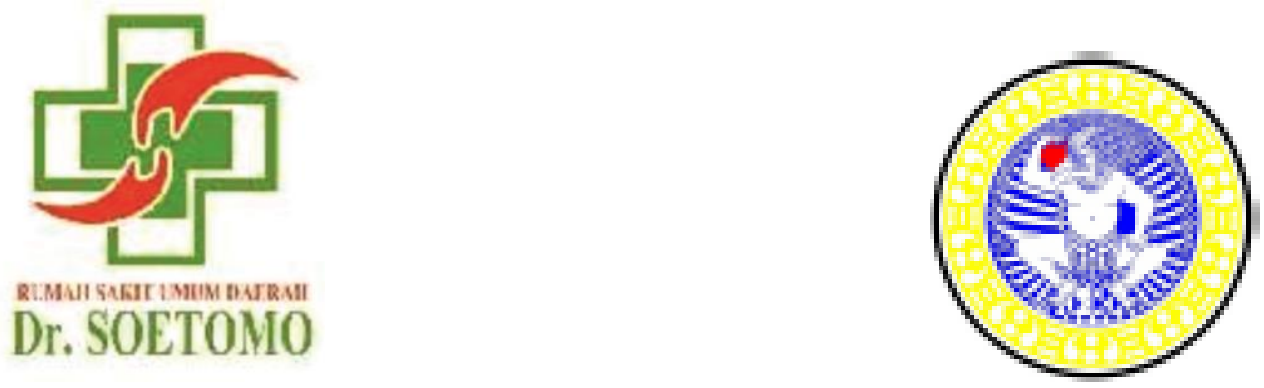

\title{
Neuroleptisasi Cepat, Masih Relevankah Saat Ini ?
}

\section{Is Rapid Neuroleptization Still Relevant Today?}

Oleh: Maya Indrawati ${ }^{1}$, Azimatul Karimah ${ }^{2}$

* Dokter Umum, peserta Program Pendidikan Dokter Spesialis I, Departemen/SMF Ilmu Kedokteran Jiwa, Fakultas Kedokteran Universitas Airlangga/RSUD Dr. Soetomo Surabaya ** Dokter Spesialis Kedokteran Jiwa/Psikiater (Konsultan), Staf Pengajar pada Departemen/SMF Ilmu Kedokteran Jiwa Fakultas Kedokteran Universitas Airlangga/ RSUD Dr.Soetomo Surabaya 


\begin{abstract}
ABSTRAK
Kegawatdaruratan di bidang psikiatri terutama agitasi menimbulkan cara baru untuk mengatasi gangguan perilaku. Agitasi adalah kumpulan ketidaksesuaian perilaku yang beresiko pada keamanan pasien dan orang yang merawat. Neuroleptisasi cepat adalah terapi yang segera dapat menenangkan pasien dengan menggunakan neuroleptik dosis tinggi dan berulang. Pemberian intramuskular dan pemberian oral sama efektifnya. Haloperidol lebih efektif dengan efek merugikan yang rendah. Antipsikotik generasi kedua mampu mengatasi gejala dengan baik meskipun perlu perhatian pada efek samping. Golongan benzodiazepin mampu menurunkan agitasi dan mengurangi penggunaan antipsikotik pada terapi kombinasi. Penggunaan antipsikotik generasi kedua mempunyai kemampuan yang kurang lebih sama dengan antipsikotik generasi pertama dalam mengatasi agitasi pada pasien dengan demensia.
\end{abstract}

Kata kunci : agitasi, neuroleptisasi cepat, antipsikotik.

\begin{abstract}
Emergencies in psychiatry, especially agitation lead to new ways to treat behavioral disorders. Agitation is a batch of mismatch behavior which risk on the safety of patients and people who care about.Rapid neuroleptization is a therapy that rapidly calm the patient. Using high-dose of neuroleptics and repetitive. Intramuscular administration is as effective as oral administration. Haloperidol is more effective with low adverse effects. The second generation of antipsychotics were able to overcome the symptoms favorably with extra attention to the side effects. Category of benzodiazepines able to reduce agitation and reduce the use of antipsychotics in the combination treatment. Application of secondgeneration antipsychotics have the same ability or less than the first generation antipsychotics in overcoming the agitation in patients with dementia.
\end{abstract}

Keywords : agitation, rapid neuroleptization, antipsychotics. 


\section{Latar Belakang}

Neuroleptisasi cepat adalah teknik yang dikembangkan di tahun 1970-an dengan tujuan untuk mengendalikan perilaku pasien dengan psikotik akut. Masih timbul perdebatan tentang keefektifan neuroleptisasi cepat yang menggunakan dosis tinggi dalam pemakaian injeksi intramuskular dan penggunaan dosis yang lebih rendah. Ditemukan bahwa tidak ada yang lebih unggul dalam penggunaan antipsikotik dosis tinggi maupun dosis yang lebih rendah dalam hasil terapi, tetapi keduanya sama-sama memberikan kerugian dengan meningkatnya efek samping. Penggunaan antipsikotik secara rasional berdasarkan kebutuhan saat diperlukan menimbulkan beberapa pertanyaan. Jika kita tingkatkan dosis, maka hanya akan meningkatkan efek samping tanpa ada peningkatan hasil seperti yang diharapkan. Cara kerja obat pun patut dipertanyakan, apakah antipsikotik bekerja dengan meningkatnya kadar di dalam darah, atau bekerja dengan meningkatkan derajat sedasi maupun memberikan efek tenang pada pasien, atau perubahan perilaku yang mendadak pada pasien sehingga membutuhkan pemberian antipsikotik turut mempengaruhi keefektifan pemberian. Hingga saat ini studi yang membahas tentang hal seperti ini belum ditemukan (Campbell dan Simpson, 1986).

\section{Pembahasan}

\subsection{Agitasi}

Agitasi adalah kumpulan ketidaksesuaian perilaku yang tidak spesifik yang beresiko pada keamanan pasien dan orang yang merawat sehingga menghambat perawatan ataupun melemahkan fungsi seseorang (Yildiz dkk, 2003; Citrome, 2002).

\subsection{Penanganaan Agitasi}

Restraint, terutama ditujukan pada pasien yang cenderung bertindak kasar dan diluar kemauannya dalam suatu tempat perawatan,dan seharusnya dilakukan bila prosedur penanganan pasien agitasi yang lain telah dilakukan. Pada beberapa pasien cara restrain dapat membuat mereka bisa lebih tenang dengan sendirinya, pada beberapa yang lain masih harus diberikan antipsikotik atau sedatif untuk membantu, dan ada juga yang membutuhkan intervensi secara verbal di saat mereka sedang direstrain (Campbell dan Simpson, 1986). 
Chemical restrain merujuk pada pembatasan gerak pasien dengan dengan penggunaaan bahan kimia dengan tujuan agar pasien tidak menyakiti diri sendiri dan orang lain disamping untuk mengurangi agitasi (Fruyt dan Demyttenaere, 2004; Citrome, 2002).

\section{Neuroleptisasi Cepat dengan Antipsikotik}

\subsection{Fakta}

Saat ini telah banyak digunakan antipsikotik sebagai "chemical restrain" yang tidak hanya lebih manusiawi tetapi juga lebih efektif dibandingkan restrain secara fisik (Thomas dkk, 1992). Pengobatan awal untuk pasien dengan kondisi agitasi akut adalah dengan membuat pasien berada dalam kondisi stupor atau tidak sadar atau kondisi apapun yang membuat pasien tertidur. Dikatakan dalam penelitian bahwa tidur yang terjadi tidak cukup menurunkan agitasi sebagai bagian dari gejala psikotik. Selain itu, penggunaan obat secara oral dalam mengatasi agitasi sama efektifnya dengan pemberian secara intramuskular, dan pemberian secara intramuskular secara signifikan terbukti tidak memberikan awal mula kerja yang lebih cepat dalam penanganan pertama pasien dengan agitasi (Yildiz dkk, 2003).

\subsection{Penggunaan Neuroleptisasi Cepat}

Sejak lebih dari 50 tahun obat-obatan yang digunakan dalam penanganan skizofrenia dan gangguan psikotik lain dikenal dengan nama "transquillizers", "neuroleptics", "ataractics", dan "anti schizophrenic agent". Hingga saat ini pun penggunaan nama masih diserahkan kepada pengguna obat-obatan tersebut (King dan Voruganti, 2002).

Definisi dari neuroleptisasi cepat adalah metode penggunaan neuroleptik secara berulang dibawah pengawasan untuk mengurangi gejala secepat mungkin, mengurangi ketakutan dan mengurangi resiko menyakiti diri sendiri dan orang lain (McGinnis dan Foote, 1986). Neuroleptisasi cepat menggunakan antipsikotik dosis tinggi untuk mengatasi kondisi psikotik akut, dan diharapkan gejala psikotik yang timbul dapat dengan cepat dihilangkan. Dalam suatu studi didapatkan bahwa neuroleptisasi cepat tidak lagi efektif dibandingkan dengan penggunaan antipsikotik dalam dosis standar untuk mengatasi keluhan yang sama (De Fruyt dan Demyttenaere, 2004).

\subsection{Teknis Neuroleptisasi Cepat}

Dalam penggunaan neuroleptisasi cepat klinisi perlu memperhatikan denyut nadi, tekanan darah, pernafasan dan suhu tubuh pasien sebelum diberikan. Tekanan darah harus 
diperhatikan setiap 15 sampai 30 menit setelah pemberian neuroleptik. Bila neuroleptisasi cepat berhasil diberikan, tanda-tanda vital tetap harus rutin diperhatikan untuk mencegah hipotensi orthostatik yang mungkin terjadi sebagai efek samping penggunaan neuroleptik (McGinnis dan Foote, 1986).

\subsection{Keuntungan - Kerugian Neuroleptisasi Cepat (Thomas dkk, 1992)}

Beberapa pasien mengalami hipotensi yang tidak diduga terutama setelah penggunaan obat dari kelompok haloperidol. Penting untuk diperhatikan bahwa penurunan tekanan darah terjadi karena dua alasan, yaitu : pasien dengan chemical restraint mungkin memiliki penyebab lain yang menimbulkan hipotensi dan bertumpang tindih dengan penggunaan antipsikotik, alasan lain pasien yang mengalami hipotensi setelah pemberian chemical restraint tidak merasa perlu dilakukan tatalaksana yang lengkap untuk mencari penyebabnya. Droperidol dipercaya hanya memiliki sedikit efek pada ekstra piramidal dibandingkan haloperidol pada pasien agitasi. Torsade de Pointes yang terjadi karena adanya prolonged $Q$ $T$ interval dilaporkan sebagai akibat pemberian haloperidol tetapi hal ini lebih kecil kemungkinannya dibandingkan dengan pemberian kelompok fenotiazin yang lain.

\section{Neuroleptisasi Cepat, Masih Relevankan Saat Ini ?}

\subsection{Monoterapi Antipsikotik}

Pada awalnya digunakan dosis besar pada penggunaan antipsikotik yang mempunyai potensi rendah seperti klorpromazin dalam neuroleptisasi cepat. Efek sedasi yang berlebihan, hipotensi yang signifikan, iritasi pada tempat injeksi dan aritmia pada jantung (berhubungan dengan efek histamin, kolinergik, dan antagonis $\alpha$ adrenergik) menuntun pada pengurangan penggunaan antipsikotik dengan potensi rendah. Dalam dua studi yang membandingkan pemberian intramuskular dan pemberian oral antipsikotik tipikal untuk mengatasi pasien yang tidak bersedia mendapatkan perawatan dan mempertanyakan prosedur perawatan, kedua cara penanganan ini sama efektifnya (Battaglia, 2005).

Secara keseluruhan literatur banyak mempublikasikan bahwa haloperidol merupakan antipsikotik tipikal yang sering digunakan dalam penanganan agitasi akut hingga saat ini. Masalah utama dalam penggunaan haloperidol adalah gejala ekstra piramidal (EPS) antara lain distonia, akatisia dan gejala mirip parkinson (Battaglia, 1997 \& 2005; Gabbard, 2007). Haloperidol mempunyai kemungkinan cukup rendah untuk menimbulkan efek pemanjangan 
interval QT, juga dianggap sebagai antipsikotik dengan resiko rendah menurunkan ambang kejang (Battaglia, 2005). Haloperidol dan klorpromazin mempunyai keefektifan dan efek samping yang mewakili profil antipsikotik generasi I (Gabbard, 2007). Beberapa pasien yang mendapat terapi klorpromazin menunjukkan gejala hipotensi yang cukup berat, sedasi yang berat, efek otonomik dan sindrom ekstra piramidal dalam taraf sedang (Currier dan Trenton, 2002).

Droperidol diketahui mempunyai kemampuan yang lebih dibandingkan haloperidol dalam mengatasi agitasi dan mempunyai onset yang lebih cepat bila diberikan secara intramuskular dan waktu paruh yang pendek (Thomas dkk, 1992). Dibandingkan haloperidol, penggunaan droperidol pada pasien dengan agitasi berat mempunyai mula kerjanya sedikit lebih cepat (efek menenangkan secara signifikan 10-15 menit), membutuhkan injeksi yang lebih sedikit, efek sedasi yang lebih baik dengan efek merugikan yang hampir sama (Battaglia, 2005). Droperidol sempat menjadi obat pilihan dalam mengatasi agitasi berat. Namun di tahun 2001 pabrik menarik droperidol dari pasaran Eropa dan Amerika Serikat karena adanya isu "black box warning" karena perhatian yang besar atas resiko aritmia pada jantung karena adanya pemanjangan QT interval (Battaglia, 2005).

Perkembangan serotonin-dopamin antagonis atau yang lebih dikenal dengan antipsikotik atipikal adalah suatu kemajuan dalam pengobatan pasien psikotik dan mampu mengubah cara pemberian obat dalam psikiatri (Battaglia, 2005). Pemberian antipsikotik atipikal akan sangat bermanfaat pada pasien mengalami disforia selama masa pengobatan yang terkait sebagai efek pengobatan penurunan agitasi (Battaglia, 2005). Risperidon dapat memperbaiki gejala positif dan gejala negatif pada skizofrenia dan obat ini mempunyai efek yang cukup rendah untuk menyebabkan sindoma ekstra piramidal bila digunakan dalam dosis yang dianjurkan. Czobor dkk dalam analisanya yang membandingkan antara risperidon dan haloperidol mengatakan adanya efek yang lebih baik pada penggunaan risperidon untuk mengatasi agresi pada pasien (Currier dan Trenton, 2002).

Olanzapin menunjukkan keefektifannya dalam mengatasi gejala positif, negatif, dan afektif pada skizofrenia. Potensi antihistaminergik (H1) yang lebih dari 160 kali difenhidramin, dapat menjelaskan hubungan efek yang merugikan baik berupa sedasi maupun peningkatan berat badan. Sediaan olanzapin intramuskular dikatakan lebih efektif dibandingkan haloperidol dalam mengatasi agitasi akut pada skizofrenia. Namun diperlukan 
studi lebih lanjut mengenai keefektifan dan kerugian penggunaan olanzapin intramuskular dalam kondisi kegawatdaruratan (Currier dan Trenton, 2002; Citrome, 2002).

Olanzapin intramuskular sebaiknya tidak diberikan bersamaan dengan obat-obatan lain terutama golongan benzodiazepin (atau obat yang menekan susunan saraf pusat), dan menjadi perhatian selanjutnya untuk keamanan pemberian pada pasien dengan intoksikasi alkohol atau bahan sedatif lain (Battaglia, 2005; Citrome, 2002). Ziprasidon mempunyai kecenderungan untuk pemanjangan interval QT, khususnya bila diberikan bersamaan dengan obat yang juga menyebabkan pemanjangan gelombang QT atau bila ada penyakit yang menyebabkan pemanjangan gelombang QT (Battaglia, 2005; Citrome, 2002). Injeksi intramuskular ziprasidon ditoleransi dengan baik dibandingkan injeksi intramuskular haloperidol (dengan berkurangnya gejala ekstra piramidal), dan dapat diubah menjadi sediaan peroral dengan sedikit efek samping yang merugikan (Citrome, 2002). Ziprasidone tidak mempunyai efek bertambahnya berat badan pada penggunaan jangka waktu lama (Citrome, 2002).

\subsection{Monoterapi Benzodiazepin}

Benzodiazepin memfasilitasi neurotransmitter $G A B A$ dan kerjanya bertanggung jawab menenangkan pasien yang sedang dalam kondisi agitasi. Benzodiazepin tidak menyebabkan sindroma ekstra piramidal ataupun efek pada jantung secara signifikan, selain itu memiliki efek penekanan sistem pernafasan, ataksia, sedasi yang sangat kuat (Citrome, 2002; Currier dan Trenton, 2002; Battaglia, 1997 \& 2005).

Beberapa studi menunjukkan bahwa lorazepam memiliki keefektifan yang setara dengan haloperidol dalam penanganan psikotik maupun agitasi karena kondisi manik serta beberapa indikasi lain. Dalam pemberian lorazepam intramuskular $2 \mathrm{mg}$ dibandingkan dengan haloperidol intramuskular $5 \mathrm{mg}$, menunjukkan lorazepam teratas dalam kemampuan menangani agresi dan gangguan fungsi secara keseluruhan, dan juga mempunyai efek sedasi yang lebih besar dibanding haloperidol (Citrome, 2002; Currier dan Trenton, 2002; Battaglia, 1997 \& 2005). Klonazepam dibandingkan dengan haloperidol memiliki efek yang lebih lambat dalam menenangkan pasien psikotik dengan agitasi. Secara keseluruhan klonazepam memiliki keefektifan yang terbatas dalam mengatasi agitasi akut (Battaglia, 2005). Diazepam selalu dikontraindikasikan karena waktu paruhnya yang panjang hingga mencapai 20 jam. 
Dosis diazepam yang melampaui $50 \mathrm{mg} /$ hari akan memberikan efek sedasi, ataksia dan disatria yang menonjol (Citrome, 2002; Currier dan Trenton, 2002; Battaglia, 2005).

\subsection{Kombinasi Antipsikotik dengan obat yang lain}

Lorazepam digunakan sebagai kombinasi dengan haloperidol untuk memberikan efek menenangkan yang lebih cepat pada pasien psikotik dengan agitasi. Dalam kenyataannya ditemukan bahwa terapi kombinasi (lorazepam $2 \mathrm{mg}$ dan haloperidol $5 \mathrm{mg}$ ) menunjukkan keefektifan dua kali lipat dibandingkan penggunaan terapi tanpa kombinasi (lorazepam $2 \mathrm{mg}$ atau haloperidol 5 mg) (Battaglia, 1997; Currier dan Trenton, 2002). Pengobatan dengan menggunakan kombinasi bertujuan untuk mencapai target penyebab agitasi yang berbeda. Selain itu juga menunjukkan adanya pengurangan gejala agitasi dengan cepat, mengurangi masa isolasi dan restrain, mengurangi kebutuhan akan injeksi, mengurangi penggunaan antipsikotik yang dibutuhkan sehingga dapat mengurangi angka kejadian sindroma ekstra piramidal. Efek sindroma ekstra piramidal yang kecil merupakan bukti bahwa dengan terapi kombinasi menginduksi efek neuroleptik pada benzodiazepin, dan merupakan konsekwensi dari kebutuhan antipsikotik yang lebih rendah (Battaglia, 2005). 


\subsection{Tata Laksana Agitasi Saat Ini}

Dibawah ini adalah alur penanganan agitasi pada pasien dengan agitasi akut yang perilakunya tidak terkontrol.

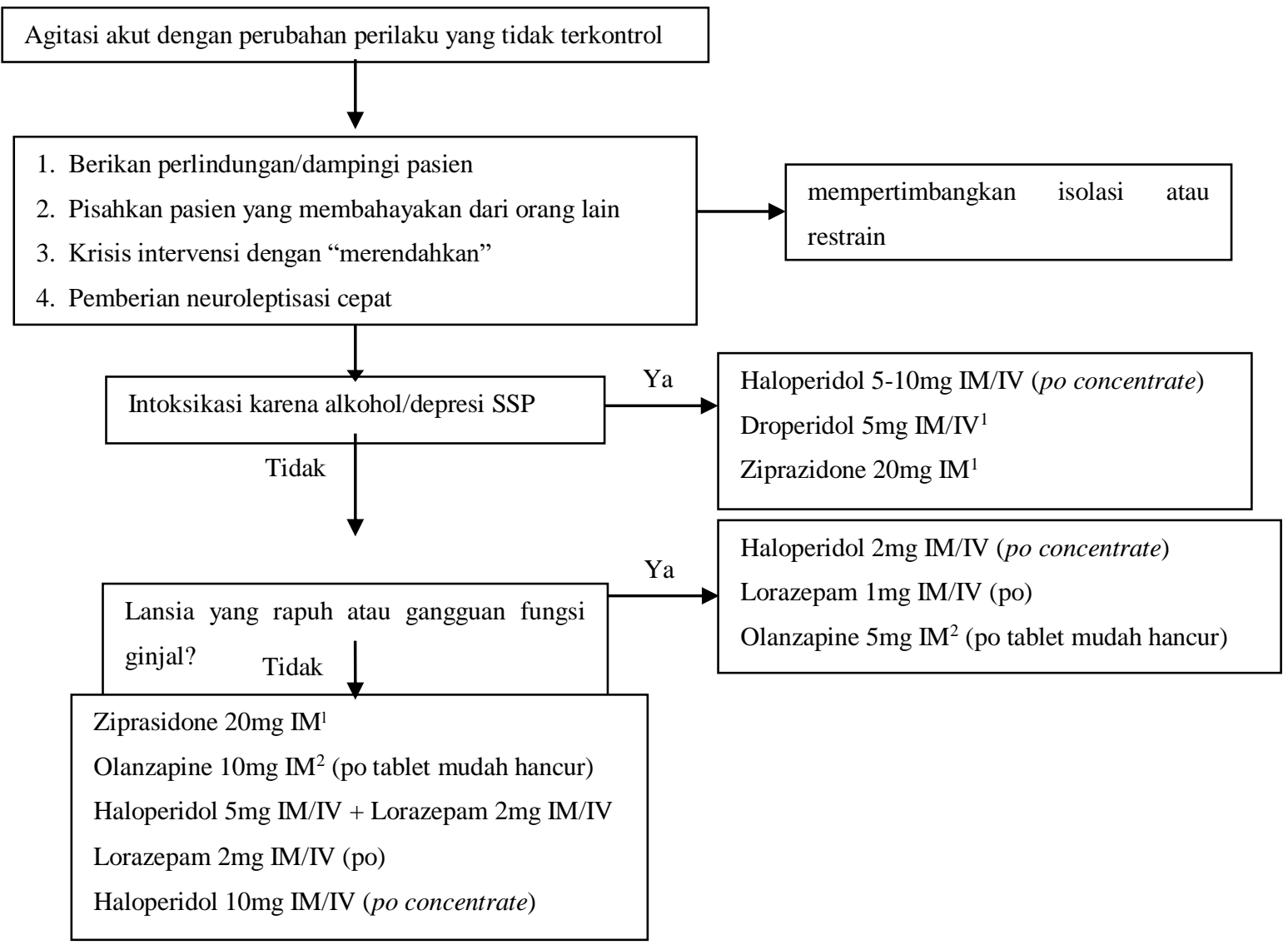

Gambar 2.1 Algoritma Tatalaksana Agitasi Akut dengan Perubahan Perilaku. Keterangan : 1 Jangan digunakan pada pasien dengan peningkatan QT interval, 2 Jangan diberikan bersamaan dengan obat yang dapat menyebabkan depresi susunan saraf pusat secara intramuskular (IM)/intravena (IV), Po=peroral (Battaglia, 2005).

Algoritma diatas digunakan bila metode secara psikologis dan lingkungan tidak cukup untuk mengontrol keluhan agitasi akut dan mengharuskan pasien untuk lebih aktif dalam menjalani pengobatan. Dapat dilakukan perlindungan/pendampingan terhadap pasien, memisahkan pasien dari orang lain, intervensi untuk mengendalikan pasien, diberikan neuroleptisasi cepat sebagai pilihan utama, dan mempertimbangkan dilakukan isolasi atau restrain yang perlu disiapkan disaat yang sama. Untuk pasien dengan agitasi yang tidak terlalu berat dapat diberikan sediaan peroral. Pada pasien yang mengalami intoksikasi alkohol 
/adanya depresi SSP, atau bila pasien lansia yang rapuh maupun mengalami gangguan fungsi ginjal perlu dipertimbangkan obat yang akan dipakai.

Dari penelitian terbaru dalam The American Psychiatric Association Practice Guideline on The Use of Antipsychotics to Treat Agitation or Psychosis in Patients with Dementia, disimpulkan bahwa penggunaan antipsikotik generasi kedua (olanzapin, quetiapin, risperidon) mempunyai kemampuan yang kurang lebih sama dengan antipsikotik generasi pertama yang dalam hal ini adalah haloperidol dalam mengatasi agitasi pada pasien dengan demensia.

\section{Ringkasan}

Agitasi adalah kumpulan ketidaksesuaian perilaku yang tidak spesifik yang beresiko pada keamanan pasien dan orang yang merawat sehingga menghambat perawatan ataupun melemahkan fungsi seseorang, disertai perilaku yang tidak terkontrol hingga membutuhkan perhatian pengobatan yang segera. Neuroleptisasi cepat adalah terapi yang segera dapat menenangkan pasien menggunakan neuroleptik dosis tinggi secara berulang dibawah pengawasan untuk mengurangi gejala secepat mungkin, sehingga mengurangi ketakutan dan resiko menyakiti diri sendiri dan orang lain. Pemberian intra muskular dan pemberian oral antipsikotik tipikal sama efektifnya.

Haloperidol lebih efektif dengan efek merugikan yang rendah, dan dapat menurunkan ambang kejang. Antipsikotik generasi kedua mampu mengatasi gejala positif, negatif, maupun afektif dengan baik meskipun perlu mendapat perhatian pada efek kenaikan berat badan, kenaikan kadar prolaktin dan efek metabolik lain, serta terjadinya peningkatan interval gelombang QT. Benzodiazepine dengan efek sedasi sangat kuat dan anti cemas mampu menurunkan agitasi, memiliki efek penekanan sistem pernafasan dan ataksia. Penggunaan terapi kombinasi bertujuan untuk mencapai target penyebab agitasi yang berbeda dan lebih cepat, sehingga kebutuhan antipsikotik lebih rendah.

Dari penelitian terbaru dalam The American Psychiatric Association Practice Guideline on The Use of Antipsychotics to Treat Agitation or Psychosis in Patients with Dementia, disimpulkan bahwa penggunaan antipsikotik generasi kedua (olanzapin, quetiapin, risperidon) mempunyai kemampuan yang kurang lebih sama dengan antipsikotik generasi pertama yang dalam hal ini adalah haloperidol dalam mengatasi agitasi pada pasien dengan demensia (Fotchmann, L.J., 2016). 


\section{DAFTAR PUSTAKA}

Battaglia, J. et al., 1997. Haloperidol, lorazepam, or both for psychotic agitation? A multicenter, prospective, double-blind, emergency department study. American Journal of Emergency Medicine, 15(4), pp.335-340.

Battaglia, J., 2005. Pharmacological management of acute agitation. Drugs, 65(9), pp.1207-1222.

Campbell, R. \& Simpson, G.M., 1986. Alternative approaches in the treatment of psychotic agitation. Psychosomatics, 27 (1 Suppl), pp.23-27. Available at: http://dx.doi.org/10.1016/S0033-3182(86)72735-7.

Citrome, L., 2002. Atypical antipsychotics for acute agitation. New intramuscular options offer advantages. Postgrad.Med, 112(0032-5481 (Print)), pp.85-86.

Fochtmann, L.J., 2016. THE AMERICAN PSYCHIATRIC ASSOCIATION Antipsychotics TO Treat Agitation OR Guideline Writing Group.

De Fruyt, J. \& Demyttenaere, K., 2004. Rapid tranquilization: New approaches in the emergency treatment of behavioral disturbances. European Psychiatry, 19(5), pp.243-249.

Currier,G.W. \& Trenton,A., 2002. Pharmacological treatment of psychotic agitation. CNS Drugs, 16(4), pp.219-228. Available at: http://ovidsp.ovid.com/ovidweb.cgi?T=JS\&PAGE=reference $\& D=$ emed5\&NEWS=N\& $\mathrm{AN}=2002168637$.

Gabbard, G.O.M., 2007. Treatment of a psychiatric disorder. ,chapter 20.

King, C. \& Voruganti, L.N.P., 2002. What's in a name? The evolution of the nomenclature of antipsychotic drugs. Journal of Psychiatry and Neuroscience, 27(3), pp.168-175.

McGinnis, and Foote, K., 1986. Rapid Neuroleptization. Journal of Psychosocial nursing and Mental Health Services.

Thomas, H., Schwartz, E. \& Petrilli, R., 1992. Droperidol versus haloperidol for chemical restraint of agitated and combative patients. Annals of Emergency Medicine, 21(4), pp.407-413.

Yildiz, a, Sachs, G.S. \& Turgay, a, 2003. Pharmacological management of agitation in emergency settings. Emergency medicine journal : EMJ, 20(4), pp.339-346. 